\title{
Subtitusi Fermentasi Daun Lamtoro (Leucaena leucocephala) pada Pakan Udang Vaname (Litopenaeus vannamei) terhadap Retensi Potein dan Energi
}

\section{Subtitution Leaf Fermentation Leucaena (Leucaena leucocephala) on Feed vaname shrimp (Litopenaeus vannamei) for Retention of Protein and Energy}

\author{
Rheza Ariyandra ${ }^{1}$, Agustono $^{2}$ dan Woro Hastuti Satyantini ${ }^{2 *}$ \\ ${ }^{1}$ Budidaya Perairan, Fakultas Perikanan dan Kelautan Universitas Airlangga, Surabaya 60115; \\ ${ }^{2}$ Departemen Kelautan, Fakultas Perikanan dan Kelautan Universitas Airlangga, Surabaya 60115. \\ *worohastuti79@gmail.com
}

\begin{abstract}
Abstrak
Sistem budidaya intensif menyebabkan ketergantungan yang besar terhadap penggunaan pakan buatan (Heptarina et al., 2010). Pakan merupakan komponen yang sangat penting untuk menentukan keberhasilan budidaya udang (Soemardjati dan Suriawan, 2006). Menurut Haryanto dan Djajanegara (1993) daun lamtoro mengandung protein, kalsium dan energi yang tinggi. Kandungan pada daun lamtoro merupakan bahan pakan sumber protein karena pada tanaman ini terdapat asam amino esensial lisin dan leusin yang sangat tinggi (D'Mello and Fraser, 1981). Pertimbangan untuk pemilihan bahan pakan sebaiknya dilakukan sesuai dengan ketentuan bahan pakan yaitu mudah didapat, harganya murah, kandungan nutrisi tinggi dan tidak bersaing dengan manusia (Handajani dkk., 2010). Menurut Mathius (1993), lamtoro sebagai hijauan yang berkualitas belum dimanfaatkan secara optimal dan belum banyak dikomersilkan. Lamtoro merupakan sumber daya hayati yang potensial untuk digunakan sebagai pakan dengan dihasilkan limbah hijauan bernilai nutrisi yang cukup (Widiastuti, 2007). Penelitian tentang subtitusi menggunakan fermentasi tepung daun lamtoro merupakan suatu hal yang perlu dilakukan karena penggunaan fermentasi tepung daun lamtoro diharapkan dapat meningkatkan kualitas pakan dan menjadikannya sebagai suatu bahan pakan alternatif yang dapat diberikan untuk meningkatkan produksi budidaya. Penelitian ini adalah penelitian dengan metode eksperimental menggunakan Rancangan Acak Lengkap (RAL) dengan empat perlakuan dan lima ulangan. Hasil dari penelitian ini akan dianalisis secara deskriptif dalam bentuk data dan tabel. Data yang diperoleh, diolah dengan menggunakan Analysis of Variance (ANOVA) untuk mengetahui pengaruh perlakuan yang diberikan apabila berbeda nyata, kemudian dilanjutkan dengan uji Jarak Berganda Duncan (Duncan's Multiple Range Test) dengan tingkat kesalahan 5\% untuk mengetahui perlakuan yang terbaik.
\end{abstract}

Kata kunci : Pakan, Udang Vaname, Fermentasi, Subtitusi, Daun Lamtoro, Retensi Protein, Retensi Energi.

\begin{abstract}
Intensive aquaculture systems causing heavy reliance on the use of artificial feed (Heptarina et al., 2010). Feed is a crucial component to the success of shrimp farming (Soemardjati and Suriawan, 2006). According to Haryanto and Djajanegara (1993) lamtoro leaves contain protein, calcium and energy. The content of the leaves lamtoro a source of protein for feed ingredients in this plant are essential amino acids lysine and leucine were very high (D'Mello and Fraser, 1981). The consideration for the selection of feed materials should be done in accordance with the provisions of the feed material that is readily available, low cost, high nutrient content and do not compete with humans (Handajani et al., 2010). According to Matthew (1993), leucaena as forage quality has not been used optimally and not much commercialized. Lamtoro a potential biological resources to be used as feed to the waste generated sufficient forage nutritional value (Widiastuti, 2007). Research on the use of fermented flour substitution lamtoro leaf is a matter that needs to be done because of the use of fermented flour lamtoro leaf is expected to improve the quality of feed and make it as an alternative feed ingredient that can be given to increase aquaculture production. This research is the experimental method using a completely randomized design (CRD) with four treatments and five replications. The results of this study will be analyzed descriptively in the form of data and tables. Data obtained, processed using Analysis of Variance (ANOVA) to determine the effect of different treatments applied if real, then continued with Duncan's Multiple Range Test (Duncan's Multiple Range Test) with a 5\% error rate to determine the best treatment.
\end{abstract}

Keywords: Feed, Vaname Shrimp, Fermentation, Substitution, Leucaena Leaf, Protein Retention, Retention Energy. 


\section{PENDAHULUAN}

Budidaya udang vaname secara intensif dilakukan untuk meningkatkan dan memenuhi produksi udang di pasaran. Sistem budidaya intensif menyebabkan ketergantungan yang besar terhadap penggunaan pakan buatan (Heptarina et al., 2010). Pakan merupakan komponen yang sangat penting untuk menentukan keberhasilan budidaya udang (Soemardjati dan Suriawan, 2006). Kebutuhan protein udang yang tinggi menyebabkan produksi pakan udang menjadi mahal. Tinggi rendahnya harga pakan ditentukan oleh besar kecilnya protein yang terkandung dalam pakan (Sumeru dan Suzy, 1992). Bahan pakan sumber protein nabati yang umum digunakan dalam formulasi pakan ikan adalah kedelai, namun ketersediaannya terbatas. Pertimbangan untuk pemilihan bahan pakan sebaiknya dilakukan sesuai dengan ketentuan bahan pakan yaitu mudah didapat, harganya murah, kandungan nutrisi tinggi dan tidak bersaing dengan manusia (Handajani dkk., 2010). Menurut Mathius (1993), lamtoro sebagai hijauan yang berkualitas belum dimanfaatkan secara optimal dan belum banyak dikomersilkan. Menurut Haryanto dan Djajanegara (1993), daun lamtoro mengandung protein, kalsium dan energi yang tinggi. Daun lamtoro memiliki komposisi kimia yaitu bahan kering $97,89 \%$, protein kasar $23,83 \%$, bahan ekstrak tanpa nitrogen (BETN) 31,0509\%, serat kasar 23,5877\%, lemak 11,68 dan abu 7,73\% (Putri,2012), sedangkan kalsium dan fosfor berturut-turut antara 1,90 - 3,20\% dan $0,15-0,35 \%$ dari bahan kering (Askar, 1997).

\section{METODOLOGI PENELITIAN}

\section{Tempat dan Waktu Penelitian}

Penelitian ini dilaksanakan pada tanggal 22 Januari 2015 - 12 Maret 2015 di Laboratorium Pendidikan Fakultas Perikanan dan Kelautan Universitas Airlangga Surabaya.

\section{Bahan dan Alat Penelitian}

\section{Bahan Penelitian}

Bahan yang digunakan dalam penelitian ini adalah udang vaname (Litopenaeus vannamei) ukuran konsumsi yang diperoleh dari Situbondo dengan berat berkisar 8-9 g/ekor sebanyak 200 ekor. Bahan pakan yang digunakan dalam penelitian ini adalah daun lamtoro, tepung ikan, bungkil kedelai, dedak halus, tepung tapioka dan premix. Bahan untuk fermentasi menggunakan probiotik PF yang mengandung bakteri Lactobacillus sp, Nitrosomonas sp., Bacillus spp dengan komposisi masing-masing $106 \mathrm{CFU} / \mathrm{ml}$. Larutan fermentor (aquades $10 \mathrm{ml}$ dan tetes 
tebu 3\%). Klorin yang digunakan untuk sterilisasi akuarium.

\section{Alat Penelitian}

Alat yang digunakan dalam penelitian adalah akuarium, filter, seser, selang, penggilingan, pengayakan, timbangan, baskom, alat pencetak pellet, oven, plastik, gunting, kertas label, loyang, $\mathrm{pH}$ meter, termometer, refraktometer, amonia dan DO test kit.

\section{Metode Penelitian}

\section{Rancangan Penelitian}

Metode penelitian adalah eksperimental. Rancangan yang digunakan dalam penelitian ini adalah Rancangan Acak Lengkap (RAL) dengan empat perlakuan dan lima ulangan. Perlakuan pada penelitian ini adalah sebagai berikut :

$\mathrm{P}_{0}$ : Pakan dosis $40 \%$ bungkil kedelai, 0\% Fermentasi Tepung Daun Lamtoro.

$\mathrm{P}_{1}$ : Pakan dosis 10\% bungkil kedelai, $30 \%$ Fermentasi Tepung Daun Lamtoro.

$\mathrm{P}_{2}$ : Pakan dosis $20 \%$ bungkil kedelai, $20 \%$ Fermentasi Tepung Daun Lamtoro. $\mathrm{P}_{3}$ : Pakan dosis $30 \%$ bungkil kedelai, $10 \%$ Fermentasi Tepung Daun Lamtoro.

\section{Prosedur Kerja}

\section{Pembuatan Fermentasi Tepung Daun}

\section{Lamtoro}

Bagian daun yang diambil adalah daun yang terletak pada bagian ujung hingga tengah batang, Daun lamtoro yang telah direndam kemudian dikeringkan dengan sinar matahari selama tiga hari. Daun lamtoro yang telah kering digiling menggunakan mesin penggiling setelah itu di saring dengan ukuran satu millimeter sehingga menjadi tepung sebanyak satu kilogram. Tepung direndam dengan air selama satu hari untuk menghilangkan kadar mimosin pada daun lamtoro tersebut. Tepung yang telah direndam kemudian disaring menggunakan saringan berukuran satu milimeter dan dikeringkan dengan suhu $27-30^{\circ} \mathrm{C}$ selama 24 jam hingga didapatkan berat keseluruhan 600 gram, setelah itu tepung daun lamtoro dimasukkan ke dalam plastik. Bahan pakan tersebut dibagi menjadi 12 kantung plastik dan setiap plastik diisi tepung dengan berat 50 gram. Probiotik PF yang mengandung bakteri Lactobacillus sp., Trichoderma sp., Nitrosomonas sp., Bacillus spp. dengan dosis $8 \%$ dari berat tepung daun lamtoro dituang ke dalam baki dan di campurkan dengan larutan fermentor. Larutan fermentor dibuat dengan cara dengan mencampurkan aquades $10 \mathrm{ml}$ dan tetes tebu $3 \%$ dari jumlah tepung daun lamtoro sampai merata untuk mempertahankan $\mathrm{pH}$ daun lamtoro selama proses fermentasi. Campuran larutan fermentor dengan probiotik PF tersebut dimasukkan dan diaduk merata di dalam kantung plastik berisi tepung daun lamtoro sebanyak 50 
gram setelah itu diikat dan kantung plastik diberi lubang lalu disimpan pada suhu ruang selama tujuh hari. Setelah itu hasil fermentasi tepung daun lamtoro dipanen dalam bentuk moist dan siap digunakan sebagai subtitusi tepung kedelai dalam pembuatan pakan.

\section{Pembuatan Pakan Perlakuan}

Tepung daun lamtoro yang telah ditimbang sesuai perlakuan lalu dicampur dengan bungkil kedelai sesuai dosis perlakuan P1, P2 dan P3. Ransum pakan yang telah jadi kemudian dimasukan ke dalam loyang dan dikukus selama 10 menit. Setelah pakan siap, kemudian dicetak dengan menggunakan mesin pellet atau mesin penggiling daging. Pellet yang sudah setengah jadi kemudian dikeringkan dengan suhu $60^{\circ} \mathrm{C}$ selama 24 jam dengan menggunakan oven, setelah di oven selama 24 jam pellet siap untuk digunakan. Pakan uji adalah pakan buatan berbentuk pellet kering yang ukurannya disesuaikan dengan ukuran bukaan mulut udang.

\section{Parameter Penelitian}

Parameter utama pada penelitian ini adalah Retensi Protein dan Retensi Energi pada udang vaname. Perhitungan Retensi Protein dilakukan dengan menghitung presentasi dari pengurangan jumlah protein dalam tubuh udang pada akhir penelitian dan jumlah protein dalam tubuh udang pada awal penelitian dibagi jumlah protein yang diberikan. Nilai retensi protein menunjukan indeks deposisi protein sebagai jaringan tubuh (dimanfaatkan bagi pertumbuhan) yang dinyatakan dalam persen. Retensi Energi merupakan gambaran dari banyaknya energi yg tersimpan dalam bentuk jaringan di tubuh ikan dibagi dengan banyaknya energi dalam pakan yang dikonsumsi (Hariati, 2009). Penggunaan energi pada ikan dipengaruhi oleh jumlah pakan yang dikonsumsi. Penghitungan Retensi Protein dan Retensi Energi dilakukan pada akhir penelitian.

\section{Analisis Data}

Data yang diperoleh, diolah dengan menggunakan Analysis of Variance (ANOVA) untuk mengetahui pengaruh perlakuan yang diberikan apabila berbeda nyata, kemudian dilanjutkan dengan uji Jarak Berganda Duncan (Duncan's Multiple Range Test) dengan tingkat kesalahan 5\% untuk mengetahui perlakuan yang terbaik (Kusriningrum, 2008). Nilai retensi protein didapatkan berdasarkan rumus Thung dan Shiau (1991) lalu data retensi yang diperoleh ditabulasikan dalam satu tabel, selanjutnya dianalisis dengan menggunakan analisa varian satu arah, pada taraf kepercayaan $95 \%$.

\section{HASIL DAN PEMBAHASAN}

Retensi Protein 
Retensi protein merupakan gambaran dari banyaknya protein yang diberikan, yang dapat diserap dan dimanfaatkan untuk membangun ataupun memperbaiki sel tubuh yang sudah rusak serta dimanfaatkan tubuh udang bagi metabolisme harian (Buwono, 2000). Retensi protein secara tidak langsung menggambarkan jumlah protein pakan yang dikonsumsi dan digunakan untuk membangun jaringan protein tubuh (dimanfaatkan bagi pertumbuhan) (Halver, 1988).

Berdasarkan perhitungan data dapat dilihat bahwa nilai rata-rata retensi protein tertinggi didapat pada perlakuan P0 tanpa subtitusi tepung kedelai dengan fermentasi daun lamtoro. Hal ini dapat diartikan bahwa dari setiap 35,335 gram protein pada pakan, yang dapat dimanfaatkan oleh tubuh udang vaname untuk pertumbuhannya adalah sebesar 1,456 gram $(4,121 / 100 \times 35,335)$. Berdasarkan analisa statistik menunjukkan bahwa subtitusi tepung kedelai dengan menggunakan fermentasi tepung daun lamtoro pada pakan udang vaname menunjukkan hasil yang tidak berbeda nyata $(p>0,05)$ terhadap retensi protein udang vaname. Hal tersebut menunjukkan bahwa subtitusi tepung kedelai dengan fermentasi tepung daun lamtoro pada pakan untuk udang vaname tidak dapat meningkatkan nilai retensi protein yang lebih baik dibandingkan pakan tanpa menggunakan fermentasi tepung daun lamtoro.

Berdasarkan rata - rata nilai retensi protein pada pakan perlakuan memiliki kualitas yang hampir sama dengan perlakuan kontrol. Hal ini menunjukan bahwa tidak ada penambahan retensi protein dalam tubuh udang vaname. Nutrisi yang terkandung dalam fermentasi tepung daun lamtoro hampir sama dengan nutrisi dalam tepung kedelai, dengan demikian fermentasi daun lamtoro layak digunakan sebagai bahan subtitusi pakan. Hal ini sesuai dengan pendapat Putri, (2012) yang menyatakan bahwa fermentasi tepung daun lamtoro merupakan sumber protein pakan yang potensial dan dapat digunakan sebagai bahan pakan alternatif karena kandungan proteinnya menyamai kedelai.

Dari hasil penelitian didapatkan nilai retensi protein udang vaname dengan perlakuan subtitusi tepung kedelai dengan fermentasi daun lamtoro berkisar antara 4,121 - 4,286 \%. Data retensi protein selengkapnya dapat dilihat pada Tabel 1.

Tabel 1. Rata - rata Retensi Protein

\begin{tabular}{cc}
\hline Perlakuan & Retensi Protein \pm SD \\
\hline $\mathrm{P}_{0}$ & $4,121^{\mathrm{a}} \pm 0,158$ \\
$\mathrm{P}_{1}$ & $3,837^{\mathrm{a}} \pm 0,397$ \\
$\mathrm{P}_{2}$ & $3,969^{\mathrm{a}} \pm 0,301$ \\
$\mathrm{P}_{3}$ & $4,286^{\mathrm{a}} \pm 0,169$ \\
\hline
\end{tabular}

Hasil analisa statistik menunjukkan bahwa subtitusi dengan menggunakan fermentasi daun lamtoro pada pakan udang vaname menunjukkan hasil yang tidak 
berbeda nyata $(p>0,05)$ terhadap retensi protein udang vaname. Pada tabel 1 menunjukan kenaikan retensi protein pada perlakuan P1, P2 hingga pada perlakuan P3. Terlihat dalam tabel 1 bahwa retensi protein tertinggi terdapat pada P3 $(4,286 \%)$ dan retensi protein terendah terdapat pada $\mathrm{P} 1$ $(3,837 \%)$.

\section{Retensi Energi}

Retensi energi adalah perbandingan antara jumlah energi yang tersimpan dalam bentuk jaringan ditubuh udang dengan jumlah konsumsi energi yang terdapat dalam pakan (Barrows and Hardy, 2001). Kandungan energi pada pakan digunakan oleh crustaceans untuk pertumbuhan, metabolisme, kebutuhan pemeliharaan (maintenance), ekskresi ammonia, feses dan molting (Bhavan et al., 2010).

Berdasarkan perhitungan data dapat dilihat bahwa nilai rata-rata retensi energi tertinggi didapat pada perlakuan P3 menggunakan perlakuan subtitusi tepung kedelai dengan fermentasi daun lamtoro dengan dosis $10 \%$ tepung kedelai dan $30 \%$ fermentasi tepung daun lamtoro. Hal ini dapat diartikan bahwa dari setiap 3711,420 $\mathrm{kal} / \mathrm{g}$ energi pakan yang dikonsumsi, yang dapat dimanfaatkan oleh tubuh udang vanname bagi pertumbuhannya adalah sebesar 367,43 kal/g (9,932/100 x 3711,420 $\mathrm{kal} / \mathrm{g})$.
Hasil dari analisa statistik menunjukkan bahwa subtitusi pada pakan udang vaname menunjukkan hasil yang tidak berbeda nyata $(p>0,05)$ terhadap retensi energi udang vaname. Handajani dan Widodo (2010), menyatakan bahwa tidak semua energi yang masuk dapat dicerna dan dimanfaatkan untuk pertumbuhan. Energi yang masuk akan digunakan terlebih dahulu untuk aktivitas, metabolisme, dan kebutuhan pemeliharaan (maintenance). Kemudian sisanya digunakan untuk pertumbuhan dan reproduksi. Hal ini apabila dibandingkan dengan nilai retensi proteinnya maka dapat dilihat hasilnya sama, yaitu pada analisa statistik retensi protein menunjukkan hasil yang juga tidak berbeda nyata $(p>0,05)$. Dengan hasil yang demikian maka dapat diduga bahwa terjadi keseimbangan antara jumlah kandungan energi dan protein pada pakan tiap perlakuan, sehingga kandungan energi dan protein yang mampu diretensi dalam tubuh udang vaname menunjukkan hasil yang tidak berbeda nyata $(\mathrm{p}>0,05)$.

Tacon (1987), menyatakan bahwa kelebihan atau kekurangan energi dapat menyebabkan penurunan laju pertumbuhan. Pemberian pakan dengan kandungan energi yang rendah menyebabkan penggunaan sebagian protein untuk pemenuhan kebutuhan energi, sehingga jumlah protein yang dapat 
dimanfaatkan bagi pertumbuhan udang akan berkurang

Hal ini juga didukung oleh pendapat Buwono (2000) yang menyatakan bahwa keseimbangan antara kadar energi dan protein sangat berperan penting dalam pertumbuhan, karena apabila kebutuhan energi kurang maka protein akan dipecah dan digunakan sebagai sumber energi. Pemanfaatan sebagian protein sebagai sumber energi ini akan menyebabkan pertumbuhan udang terhambat.

Dari hasil penelitian didapatkan nilai retensi energi udang vaname dengan perlakuan subtitusi tepung kedelai dengan fermentasi daun lamtoro berkisar antara 8,065 - 9,932 \%. Data retensi energi selengkapnya dapat dilihat pada Tabel 2.

Tabel 2. Rata - rata Retensi Energi

\begin{tabular}{cc}
\hline Perlakuan & Retensi Energi \\
\hline $\mathrm{P}_{0}$ & $8,065^{\mathrm{a}} \pm 0,541$ \\
$\mathrm{P}_{1}$ & $8,926^{\mathrm{a}} \pm 1,009$ \\
$\mathrm{P}_{2}$ & $9,218^{\mathrm{a}} \pm 0,764$ \\
$\mathrm{P}_{3}$ & $9,932^{\mathrm{a}} \pm 0,462$ \\
\hline
\end{tabular}

Hasil analisa statistik menunjukkan bahwa subtitusi dengan menggunakan fermentasi daun lamtoro pada pakan udang vaname menunjukkan hasil yang tidak berbeda nyata $(p>0,05)$ terhadap retensi energi udang vaname. Tabel 2 menunjukkan nilai retensi energi yang rendah pada perlakuan P0 namun retensi energi meningkat pada perlakuan P1, P2 dan P3. Terlihat dalam tabel 2 bahwa retensi energi tertinggi terdapat pada P3
$(9,932 \%)$ dan retensi energi terendah terdapat pada perlakuan P0 $(8,065 \%)$.

\section{Kualitas Air}

Data nilai kisaran parameter kualitas air pada pemeliharaan udang vaname yaitu suhu berkisar antara 28 $30^{\circ} \mathrm{C}$. Oksigen terlarut berkisar antara 6 ppm, pH 8 dan amonia berkisar antara $0-$ $0,25 \mathrm{mg} / \mathrm{l}$. . Hasil penjagaan kualitas air menunjukkan bahwa kualitas air yang ada di dalam wadah pemeliharaan dalam keadaan baik.

\section{SIMPULAN DAN SARAN}

Berdasarkan hasil penelitian dapat diperoleh kesimpulan bahwa penggunaan fermentasi tepung daun lamtoro sebagai subtitusi kedelai pada pakan udang vaname (Litopenaeus vannamei) tidak berpengaruh terhadap nilai Retensi Protein dan Retensi Energi.

\section{DAFTAR PUSTAKA}

Adiwidjaya, D., Supito dan I, Sumantri. 2008. Penerapan Teknologi Budidaya Udang VanameL. vannamei Semi Intensif pada Lokasi Tambak Salinitas Tinggi. Media Budidaya Air Payau Perekayasaan, (7): 54-72.

Afrianto, E dan E. Liviawaty. 2005. Pakan Ikan Kanisius. Yogyakarta. Hal 977.

Buwono, I. D. 2003.Kebutuhan Asam Amino Essensial dalam Ransum 
Pakan.Kanisius.Yogyakarta.11, 13, 27 hal.

Halver, J. E. 1989. Fish Nutrition. 2rd (eds). Academic Press. London. Pp. 1-23.

Handajani, Hany dan Widodo, Wahju. 2010. Nutrisi Ikan. UMM Press. Malang. 271 hal.

Hariati. 2009. Pertumbuhan, Efisiensi Kecernaan dan Eksresi Nitrogen Juvenil Udang Vaname (Litopenaeus vannamei) Pada Berbagai Kandungan Protein Pakan. Fakultas Ilmu dan Kelautan. Universitas Hasanuddin. Makassar. 35 hal.

Heptarina, Deisi. et al., 2010. Pengaruh pemberian pakan dengan Kadar Protein berbeda terhadap pertumbuhan yuwana udang putih (Litopenaeus vannamei). Prosiding Forum Inovasi Teknologi Akuakultur. Balai Riset Perikanan Budidaya air Tawar.

Indariyanti N. dan Rakhmawati. 2013. Peningkatan Kualitas Nutrisi Limbah Kulit Buah Kakao dan Daun Lamtoro Melalui Fermentasi Sebagai Basis Protein Pakan Ikan Nila. Jurnal Penelitian Pertanian Terapan Vol. 13 (2): 108-115.

Kanazawa, A., S. Teshima and M. Ondo, 1979. "Requirement of Prawn, Penaeus japonicus for Essensial Fatty Acids." In Mem Fac. Fish. Kagoshima University, 28: 27-33.

Karlina, H. P. 2012. Fermentasi Ampas Kelapa Menggunakan Trichoderma viridae subtilis Dan EM4 Terhadap Kandungan Protein dan Serat Kasar
Sebagai Bahan Alternatif Ikan. Skripsi. Program studi Budidaa Perairan. Fakultas Perikanan dan Kelautan. Universitas Airlangga. Hal 65.

Kementerian Kelautan dan Perikanan. 2009. Laporan Tahunan Dirjen Perikanan Budidaya 2009.

Kusriningrum, R. 2008. Dasar Perencanaan Percobaan dan Rancangan Acak Lengkap. Universitas Airlangga Surabaya. hal. 53-90.

Nur, A. 2011. Manajemen Pemeliharaan Udang Vaname. Direktorat Jenderal Perikanan Budidaya. Balai Besar Pengembangan Budidaya Air Payau Jepara. Jepara. 40 hal.

Parakkasi, A. 1995. Ilmu Nutrisi dan Makanan Ternak Ruminan. UI. Jakarta.

Putri, D. R. 2012. Kandungan Bahan Kering, Serat Kasar dan Protein Kasar pada Daun Lamtoro (Leucaena glauca) yang difermentasi dengan Probiotik sebagai pakan ikan. Skripsi. Program Studi Budidaya Perairan. Fakultas Perikanan dan KelautanUniversitas Airlangga. Hal 61.

Theresia J. R. T. 1999. Perbedaan Kandungan Karbohidrat Bungkil

Kedelai Asal Amerika Serikat Dan India Hasil Fraksinasi Dan Hidrolisis Enzim Komersial. IPB. Bogor. 